\title{
SMALL GROUP DISCUSSION FOR THE STUDENTS' READING COMPREHENSION OF THE SENIOR HIGH SCHOOL STUDENTS
}

\author{
Zamila Fitriani Siregar, Eka Sustri Harida \& Zainuddin \\ IAIN Padangsidimpuan \\ Email: zamilasiregar@gmail.com, haridaekasustri75@gmail.com, \& \\ zainuddin@gmail.com
}

\begin{abstract}
Abstrak
Penelitian ini mendeskripsikan tentang pengaruh strategi Small Group Discussion untuk memahami teks naratif pada siswa kelas $X$ SMK Swasta Panca Dharma Padangsidimpuan. Ada beberapa masalah dalam penelitian ini: 1). Siswa masih kesulitan dalam memahami teks, 2). Siswa masih kesulitan dalam menginterpretasikan kata-kata dan beberapa aspek-aspek penting seperti: ide pokok, struktur umum, bentuk spesifik bahasa, 3).Siswa kurang aktif dalam berpastisipasi didalam proses pembelajaran. Tujuan dari penelitian ini adalah untuk mengetahui eketifitas penggunaan Small Group Discussion pada hasil membaca pemahaman siswa. Penelitian ini merupakan penelitian eksperimen., dengan menggunakan desain pre-test dan post-test. Populasi dalam penelitian ini adalah seluruh siswa kelas X SMK Swasta Panca Dharma Padangsidimpuan. Total populasi adalah 112 siswa. Lalu, sampel penelitian ini adalah dua kelas, X A sebagai kelas eksperimen yang terdiri dari 26 siswa dan X B sebagai kelas kontrol yang terdiri dari 26 siswa. Data dikumpulkan melalui pre-test dan post-test. Untuk menganalisa data, peneliti menggunakan rumus t-test. Berdasarkan perhitungan t-test, peneliti menemukan bahwa thitung $=4.18$ dan table $=$ 1.67591. Itu artinya thitung $>$ table $(4.18>1.67591)$. Jadi, peneliti dapat menyimpulkan bahwa Ha diterima dan Ho ditolak. Ada pengaruh yang signifikan dari penggunaan strategi Small Group Discussion untuk memahami teks naratif pada siswa kelas X SMK Swasta Panca Dharma Padangsidimpuan.
\end{abstract}

Kata Kunci: Pemahaman Membaca, Kesulitan dalam Membaca, Strategi Diskusi Kelompok Kecil.

\footnotetext{
Abstract

This studies involved approximately the impact of Small Group Discussion Strategy (SGDS) on the students' reading comprehension at grade X SMK Swasta Panca Dharma Padangsidimpuan. There had been a few issues determined for the students: 1) they were given problems in comprehending the text, 2) they have problems in deciphering phrases and a few vital components which include predominant idea, normal structure, and particular language features,
} 
148 | TAZKIR: Jurnal Penelitian Ilmu-ilmu Sosial dan Keislaman

Vol. 06 No. 1 Juni 2020

3) they had been less practice to the gaining knowledge of process. The purpose of this study is to examine the effectiveness of the SGDS to the students' reading comprehension. This study turned into experimental studies with pre-test and post-test design. The population turned into all the 10th grade of SMK S Panca Dharma Padangsidimpuan., they are 112 students; and taken as sample 2 classes, they are $\mathrm{XA}$ as experimental group and $\mathrm{XB}$ as control group. To examine the information, the researcher used t-test formula. Based at the calculation of $\mathrm{t}$-test, the researcher determined that $\mathrm{t}$-count $=$ 4.18 and $\mathrm{t}$-table $=1.67591$, it means that $\mathrm{t}$-count is higher than $\mathrm{t}$-table $(4.18>1.67591)$. So, the researcher should concluded that $\mathrm{Ha}$ is accepted and Ho is rejected. It can be concluded that SGDS has big impact to student's reading comprehension at grade X SMK Swasta Panca Dharma Padangsidimpuan.

Keywords: Reading Comprehension, Difficulties in Reading, Small Group Discussion Strategy.

\section{INTRODUCTION}

Reading comprehension is understanding the text. Reading comprehension is reading a textual content through wondering at the same time as reading and connecting what the reader reads to their thoughts or history expertise in order to recognize or comprehend the textual content (Nurhamidah et al., 2018). Reading comprehension is making sense of what you read and connecting the thoughts withinside the textual content to what you already know. It additionally means remembering what you've got examine. In conclusion, reading comprehension is interesting through searching a textual content and connecting it to the reader's background knowledge in getting understanding.

Reading comprehension is the capacity of readers to apprehend a printed material or written textual content to getting which means from the writer (Harida, 2017a). Reading is one in every of language capabilities that need to be mastered with the aid of using English learners. It is likewise one of the maximum essential capabilities for the students. Reading enables students to recognize new phrases. For example, if a student reads a book approximately overseas language like English. From that book, if the students locate phrases which they do now no longer recognize the which means, the students will strive to seek the which means by using dictionary.

Reading is the process of getting the information, and comprehension if the soul of reading. When readers did not get any information from what is being 
read, it is meaningless, it means that they did not comprehend for what they read (Harida, 2017b). With reading, the readers must get comprehend, must understand the key concepts for what being read. There are many strategies, methods, or techniques that can help the readers to increase their reading comprehension.

Small group discussion is one of the cooperative gaining knowledge of strategies wherein students works in corporations of 3 or four. According to Barker, the usage of small group discussion strategies in teaching, particularly reading comprehension, will allow the scholars to get the which means of a passage with the aid of using getting data from his friends and teacher. According to Bormann in Rizki, Small Group Discussion (SGD) is something that composed 3 or greater humans running collectively to do, in reality, exact hobby or to attain a not unusual place goal (Rizki, 2017). It means a small institution is a small member of humans, work collectively through interplay whose interdependent courting lets in them to attain a mutual goal. Further, small group discussion is effective in enhancing the students' reading comprehension (Setianingsih \& Harahap, 2020). It means the usage of small group discussions in teaching reading comprehension is an appropriate alternative. According to Sagala, group discussion group is more powerful if the group includes 3-four college students, allow students to offer their critiques or thoughts to different college students easily (Sari, 2016). It approaches institution dialogue is a conversation wherein humans communicate to at least one another, sharing thoughts and critiques.

Using various strategies or method to enhance the students' reading comprehension is important. Some methods proved to improve reading comprehension as stated by two findings that Know - Want - Learn is effective to improve the students' reading comprehension (Riswanto et al., 2014; Sagala, 2019). In addition, Think - Pair - Share can also be useful for giving good effect to the students' reading comprehension (Harida et al., 2016). Based on the researchers findings above, it is known that using methods or techniques or strategies in solving the students' reading comprehension is needed, then in this article, it is exploring the effect of Small Group Discussion to students' reading 
comprehension, as known that SGD is also very useful for guiding the students' reading comprehension.

However, reading skill is problematic think for the vocational senior high school students of SMK Swasta Panca Dharma either in the espect of echievement or intelligence. The English teacher said that the students are difficult to get understanding of the English texts, they got difficult in finding the ideas, and do not know the meaning from what they read. Below the researcher reveals the reason as follows. Firstly, the students do not have many vocabularies in order to get more understanding about the text; secondly, the strategy used do not appropriate to the students' need; thirdly, many students less active in participating in the learning process. From the some problems above, researcher divided into two kinds of problems identified as; general problem and specific problem. The general problem was the students feel reading activity is so bored, the specific problem was they are lack vocabulary; the meaning of word by word in the text is not apropriate with the whole of sentence or paragraph; the teacher never applies the strategy in teaching reading. So, the problem needs solution to get the effect of student learning and improve their grades were below standard. English teacher should create the better Strategy that can increase students' reading comprehension.

This article is to give the explanation about the effectiveness of using SGD to the students' reading comprehension at for the Vocational Senior High School Students in Padangsidimpuan.

\section{METHOD}

This research is in the experimental type in aimed to know the cause effect relationship between one variable or more to other variables. The experimental class is the class that thaugh with using small group discussion strategy as a treatment and the control class is the class that taught with a treatment by convensional teaching. It was done at SMKS Panca Dharma Padangsidimpuan. The researcher chooses two classes. The sample chosen are XA consist of 26 students and XB consists of 26 students, the total samples are 52 students. To get the data from the students, the researcher collected by giving test, and the procedures of the research done by giving pre-test, treatment and 
post-test. Then, to analyze the data, the researcher has used " $t$ " test formula, it is to find out the significances of the students' reading comprehension of the two groups that have divided in to experimental and control class. If $t$-test is higher than table, the researcher can conclude that ha is accepted and ho is rejected. If $t$-test is lower that table the researcher can conclude that ha is rejected and ho is accepted.

\section{RESEARCH RESULT}

\section{Normality and Homogeny of the Test}

The normality and homogeny of the test is important to know in order to know whether the class is normal and homogeny be an experimental or control class in this research. In the table below, it is seen the result of testing both test of post-test.

Table 1

Normality and Homogeneity in Post-Test

\begin{tabular}{|l|c|c|c|c|}
\hline \multirow{2}{*}{\multicolumn{1}{c|}{ Class }} & \multicolumn{2}{|c|}{$\begin{array}{c}\text { Normality } \\
\text { Test }\end{array}$} & \multicolumn{2}{c|}{$\begin{array}{c}\text { Homogeneity } \\
\text { Test }\end{array}$} \\
\cline { 2 - 4 } & $\mathrm{x}_{\text {count }}$ & Xtable & $\mathrm{f}_{\text {count }}$ & $\mathrm{f}_{\text {table }}$ \\
\hline ExperimentalClass & -6.58 & 11.070 & \multirow{2}{*}{$4.18<2.71$} \\
\hline Control Class & -10.05 & 11.070 & \multicolumn{2}{|c|}{} \\
\hline
\end{tabular}

Based on the table above researcher calculation, the score of experiment class $\mathrm{Lo}=-6.58<\mathrm{Lt}=11.070$ with $\mathrm{n}=26$ and control class $\mathrm{Lo}=-10.05<\mathrm{Lt}=11.070$ with $\mathrm{n}=26$, and real level $\alpha 0.05$. Cause Lo $<\mathrm{Lt}$ in the both class. So, Ha was accepted. It means that experimental class and Control class were distributed normal.

The coefficient of $\mathrm{F}_{\text {count }}=4.18$ was compared with $\mathrm{F}_{\text {table. }}$. Where $\mathrm{F}_{\text {table }}$ was determined at real $\alpha 0.05$, and the different numerator $\mathrm{dk}=\mathrm{n}-1=26-1=25$ and denominator $\mathrm{dk} n-1=26-1=25$. So, by using the list of critical value at $\mathrm{F}$ distribution is got $\mathrm{F}_{0.05}=2.71$. It showed that $\mathrm{F}_{\text {count }} 4.18<\mathrm{F}_{\text {table }} 2.71$. So, the researcher concluded that the variant from the data of the Students' Reading comprehension at SMK Swasta Panca Dharma Padangsidimpuan by experimental class and Control class was homogenous. 
152 | TAZKIR: Jurnal Penelitian Ilmu-ilmu Sosial dan Keislaman

Vol. 06 No. 1 Juni 2020

\section{Description of Comparison Score of Pre-Test and Post-Test}

The students' score of reading comprehension in experimental and control class after giving the treatment to the control class. The comparison score between pre-test and post-test of experimental class can bee seen in the following table:

Table 15

The Comparison Data of Experimental Class in Pre-test and Post-Test

\begin{tabular}{|c|c|c|}
\hline Description & Pre-Test & Post-Test \\
\hline Total & 1310 & 2120 \\
\hline Highest score & 75 & 95 \\
\hline Lowest score & 35 & 65 \\
\hline Mean & 49.79 & 90.4 \\
\hline Median & 55.75 & 85.3 \\
\hline Modus & 58.9 & 87.5 \\
\hline Range & 40 & 30 \\
\hline Interval & 7 & 5 \\
\hline Standard deviation & 11.69 & 454.84 \\
\hline Variants & 289.84 & \\
\hline
\end{tabular}

Based on students' answers in experimental of pre-test and post-test, the researcher has calculated the students' score and most of students both of classes were low in reading. Experimental class consisted of 26 students (XA). The lowest score in pre-test was 35 whereas the highest score was 70 and the lowest score in post-test was 65 whereas the highest score was 95.

\section{Comparison Score of Pre-test and Post Test in Control Class}

The comparison score between pre-test and post-test of control class can bee seen in the following table: 
Table 16

The Comparison Data of Control Class in Pre-test and Post-Test

\begin{tabular}{|c|c|c|}
\hline Description & Pre-Test & Post-Test \\
\hline Total & 1050 & 1685 \\
\hline Highest score & 65 & 80 \\
\hline Lowest score & 15 & 40 \\
\hline Mean & 45.22 & 76.5 \\
\hline Median & 41.5 & 67.5 \\
\hline Modus & 43.9 & 69.8 \\
\hline Range & 50 & 40 \\
\hline Interval & 8 & 7 \\
\hline Standard deviation & 11.04 & 8.82 \\
\hline Variants & 194.84 & 123.84 \\
\hline
\end{tabular}

Based on students' answers in control class of pre-test and post-test has calculated the students' score and most of students both of classes were low in reading. Control class consisted of 26 students $(\mathrm{XB})$. The lowest score in pre-test was 15 whereas the highest score was 65 and the lowest score in post-test was 40 whereas the highest score was 80 .

\section{Comparison between Experimental and Control Class in Post-Test}

Based on students' answers in post-test in experimental and control class, the researcher has calculated the students' score and most of students both of classes increased. Experimental classconsisted of 26 students (XA), the lowest score was 65 whereas the highest score was 95. Then, most of students got raising score and their score increased very significant. Control classconsisted of 26 students (XB), the lowest score was 40 whereas the highest score was 80 . Students' score increased too but not significant.

\section{Hypothesis Test}

Based on the result, researcher used parametric test by using T-test to analyze the hypothesis. Hypothesis alternative $\left(\mathrm{H}_{\mathrm{a}}\right)$ of the research was "There 
154 | TAZKIR: Jurnal Penelitian Ilmu-ilmu Sosial dan Keislaman

Vol. 06 No. 1 Juni 2020

isthe significant effect of using Small Group Discussion Strategy on students' reading comprehension at grade $X$ SMKSwasta Panca Dharma Padangsidimpuan". Hyphotesis null (Ho) of the research was "There is no significant effect of using Small Group Discussion Strategy on students' reading comprehension at grade X SMKSwasta Panca Dharma Padangsidimpuan". Ha is accepted if $t_{\text {count }}$ is higher than table. In this case, the researcher found that $t_{\text {count }}>t_{\text {table }}$ which means that there was the significant effect of using Small Group Discussion Strategy on students' reading comprehension at grade X SMKSwasta Panca Dharma Padangsidimpuan.

Table 2

Result of T-test from the Both Averages

\begin{tabular}{|l|l|l|l|}
\hline \multicolumn{2}{|l|}{ Pre-test } & Post-test \\
\hline$t_{\text {count }}$ & $t_{\text {table }}$ & $t_{\text {count }}$ & $t_{\text {table }}$ \\
\hline 45.7 & 1.67591 & 4.18 & 1.67591 \\
\hline
\end{tabular}

Based on researcher calculation, researcher found that $t_{\text {count }} 4.18$ while ttable 1.67591 with opportunity $(1-\alpha)=1-5 \%=95 \%$ anddk $=n_{1}+n_{2}-2=26+26-2=50$. Cause $t_{\text {count }}>t_{\text {table }}(4.18>1.67591)$, it means that hypothesis $\mathrm{H}_{a}$ was accepted and $\mathrm{H}_{0}$ was rejected. So, there was the significant effect of using Small Group Discussion Strategy on students' reading comprehension at grade X SMK Swasta Panca Dharma Padangsidimpuan".

\section{DISCUSSION}

Based on the result of this research, the researcher considers that Small Group Discussion Strategy is probably suitable to teach reading comprehension. The researcher also has proved what had been stated by Umiyati said that Small Group Discussion is effective to teach reading comprehension, simple to apply, enjoy, and it help the studentsare not only able to improve their intellectual skill but also increase their social relationship than whole reading class (Sartini et al., 2018). The theory stated that Small Group Discussion is an appropriate strategy for reading comprehension, and in this research, the researcher found that the mean score of students' reading comprehension before using Small Group Discussion was 45.7 and after using Small Group Discussion was 4.18. It means 
there was the effect of using Small Group Discussion Strategy on reading comprehension.

The result above supported the previous research by some researchers. The first is Faradina Primarini Noorhaya Sari (2016); the second is Rizki (2017), and the next is Ningsih (2018) concluded that in their research, they have found that there is the significant effect of small group discussion on students' reading comprehension. The students' perspective on SGD used for their learning is positive, and it gave significant effect on reading comprehension of the students (Annamalai et al., 2015). SGD is really effective for making the students' reading comprehension become better.

Based on the explanation above, the researcher has got the effect of SGD on students' reading comprehension. Fibrina Hanung Suswanti, found that $t_{\text {count }}=(70.85>51.28)$. The researcher also found that $t_{\text {count }}$ is higher than table where $t_{\text {count }}$ was4.18and table was $1.67591(8.03>1.67591)$. It can be seen among the researches that the using of Small Group Discussion Strategy gave the effect to students' reading comprehension especially at grade X Students of SMK Swasta Panca Dharma Padangsidimpuan. It means the theory has been proved where the students able to comprehend the reading material.

Based on some findings above, it is understandable that SGD is very helpful and give the good effect of using SGD to students' reading comprehension. Therefore, Small Group Discussion Strategy has given the significant effect to the research that has been done by the researcher or the other researcher who mentioned in related finding and Small Group Discussion Strategy is highly effective to help the English teacher in teaching learning process especially in reading comprehension.

\section{CONCLUSION}

Based on the result of the research, the conclusions of this research are:

1. Students' reading comprehension at grade X SMK Swasta Panca Dharma Padangsidimpuan before using Small Group Discussion Strategy were still low. It can be seen from the students' mean score of pre-test was 49.79 in experimental class and 45.22 in control class. 
156 | TAZKIR: Jurnal Penelitian Ilmu-ilmu Sosial dan Keislaman

Vol. 06 No. 1 Juni 2020

2. The students' ability of the grade $X$ students at SMK Swasta Panca Dharma Padangsidimpuan in comprehending narrative text by using Small Group Discussion Strategy had higher score. It can be seen from the students' score of post-test, the higher score of post-test using Small Group Discussion Strategy (experiment class) is 95 and the lowest score is 65.

3. It is found that $t_{\text {count }}$ was higher than table $4.18>1.67591$ which means $\mathrm{H}_{\mathrm{a}}$ was accepted. Hence, there was significant effect of using Small Group Discussion Strategy to comprehend narrative text at grade $X$ students SMK Swasta Panca Dharma of Padangsidimpuan. 


\section{REFERENCES}

Annamalai, N., Manivel, R., \& Palanisamy, R. (2015). Small Group Discussion: Students Perspectives. International Journal of Applied and Basic Medical Research, 5(4). https://doi.org/10.4103 /2229-516x.162257

Harida, E. S. (2017a). An Evaluation on Students' Reading Motivation and Their Reading Comprehension of English Department Students IAIN Padangsidimpuan. Tazkir, 03(1), 183-194.

Harida, E. S. (2017b). Improving Students' Reading Narrative Text Comprehension through Story Mapping Technique at Grade VIII MTs N 2 Padangsidimpuan. English Education Journal, 5(02), 103-117. http://jurnal.iain-padangsidimpuan.ac.id/index.php/EEJ/article/view/1184

Harida, E. S., Siregar, F. R., \& Zuhri, I. (2016). Improving Students' Reading Comprehension by Using Think Pair Share (TPS) at Grade VIII SMP N 9 Padangsidimpuan. English Education : English Journal for Teaching and Learning, 5(1), 29. https://doi.org/10.24952/ee.v5i1.1168

Ningsih, N. (2018). Small Group Discussion Method in Teaching reading Comprehension in eight Grade Students of SMP N 3 Bantul in Academic Year 2017 / 2018 (Vol. 05) [Universitas PGRI Yogyakarta]. http://repository.upy.ac.id/1768/

Nurhamidah, S., Pulungan, S. M., \& Harida, E. S. (2018). The Analysis of the Teachers' Strategies in Teaching Reading Comprehension at SMAN 2 Padangbolak. TAZKIR: Jurnal Penelitian Ilmu-Ilmu Sosial Dan Keislaman, 04(2), 299-312.

Riswanto, Risnawati, \& Lismayanti, D. (2014). The Effect of Using KWL (Know, Want, Learned) Strategy on EFL Students' Reading Comprehension Achievement. International Journal of Humanities and Social Science, 4(7). https://www.semanticscholar.org/paper/The-Effect-of-Using-KWL(Know\%2C-Want\%2C-Learned)-onLismayanti/c2b3d05e1932ba61366dfcff74c8b4cbf5330adf

Rizki, S. (2017). The Effectiveness of Teaching Reading Comprehension through Small Group Discussion Technique of Tenth Grade Students at SMAN 1 Tulungagung in Academic Year 2016/2017 [IAIN Tulungagung]. http://repo.iaintulungagung.ac.id/5207/

Sagala, R. (2019). The Use of Know-Want-Learn (KWL ) Strategy to Improve Students ' Reading Comprehension at Second Grade MTSN 1 Padangsidimpuan. IAIN Padangsidimpuan. 
158 | TAZKIR: Jurnal Penelitian Ilmu-ilmu Sosial dan Keislaman

Vol. 06 No. 1 Juni 2020

Sari, F. P. N. (2016). The Effect of Small Group Discussion in Reading Class on Students' Reading Comprehension [University of Lampung]. http://digilib.unila.ac.id/23997/

Sartini, D., Harida, E. S., \& Rambe, S. (2018). The Comparative Study of Students' Reading Comprehension by Using Reciprocal Teaching Strategy (RTS) and Question-Answer Relationship (QAR) Startegy at Grade XI Students of MAN Sipirok. English Education: English Journal for Teaching and Learning, 6(1), 99. https://doi.org/10.24952/ee.v6i1.1241

Setianingsih, S., \& Harahap, D. I. (2020). The effect of Small Group Discussion on Teaching Inferential Reading. Jurnal Mahasiswa Fakultas Ilmu Sosial Dan Kependidikan, 1(1), 158-167. http://e-journal.potensiutama.ac.id/ojs/index.php/FISK/article/view/696/960 